Tersedia online di: http://ejournal-balitbang.kkp.go.id/index.php/ma

\title{
PENDEDERAN ABALON, Haliotis squamata KEPADATAN TINGGI DENGAN SISTEM TANGKI AIR MENGALIR
}

\author{
Gusti Ngurah Permana\#, Ibnu Rusdi, Reagan Septory, dan Hendra Agung Kurniawan \\ Balai Besar Riset Perikanan Budidaya Laut dan Penyuluhan Perikanan \\ Jl. Br. Gondol, Kecamatan Gerokgak Kabupaten Buleleng, Kotak Pos 140, Singaraja, Bali 811016
}

(Naskah diterima: 5 April 2021; Revisi final: 24 September 2021; Disetujui publikasi: 29 September 2021)

\begin{abstract}
ABSTRAK
Teknologi budidaya abalon telah tersedia dan dilakukan dengan berbagai metode budidaya pendederan dan pembesaran. Namun, hingga saat ini belum berkembang di masyarakat karena kurangnya minat pengusaha/pembudidaya abalon untuk mengaplikasikan secara komersial. Hal ini disebabkan oleh kualitas dan kuantitas benih belum stabil, pertumbuhan lambat, biaya tinggi, dan memerlukan waktu pemeliharaan lebih lama. Oleh karena itu, perlu diupayakan metode yang lebih sederhana dengan biaya murah untuk pembesaran abalon. Penelitian ini bertujuan untuk membandingkan pertumbuhan dan produksi abalon dengan padat tebar berbeda pada sistem-sistem tangki air mengalir. Benih abalon dipelihara di bak beton ukuran $12 \mathrm{~m}$ x 0,8 m x 0,8 m; kepadatan 70\%dan 80\%dari luasan dasar bak. Sementara untuk menghitung kelayakan usaha, rumus yang digunakan adalah revenue cost ratio $(\mathrm{R} / \mathrm{C})$. Hasil penelitian menunjukkan bahwa pertumbuhan panjang, lebar dan bobot cangkang pada densitas 70\% lebih baik dibandingkan dengan densitas 80\% Kepadatan 70\% menghasilkan 8,98\%peningkatan hasil biomassa dan kematian 6,51\%lebih tinggi dari kepadatan $80 \%$ Berdasarkan analisis ekonomi, sistem pembibitan ini layak secara ekonomi di mana padat tebar 70\%dari total luas dasar memiliki keuntungan finansial terbaik.
\end{abstract}

\section{KATA KUNCl: abalon; produksi massal; tangki air mengalir; pertumbuhan}

ABSTRACT: $\quad$ Nursery of abalone, Haliotis squamata, in high density with water flow-trough tank system. By: Gusti Ngurah Permana, Ibnu Rusdi, Reagan Septory, and Hendra Agung Kurniawan

Breeding technology for abalone is available, and its farming can be done using different nursery and grow-out methods. However, abalone farming has not yet been commercially practiced due to the lack of interest from fish entrepreneurs/fish farmers. This is dueto several factors related to the quality and quantity of seeds, such as inconsistent availability, slow growth, high cost, and long culture was period. Therefore, it is necessary to develop a simpler and inexpensive method to culture abalone. This research aimed to improve the rearing technique for abalone. Two concrete tanks of $12 \mathrm{~m} \times 0.8 \mathrm{~m} \times 0.8 \mathrm{~m}$ in size were used in which abalone seeds were stocked with stocking densities of $70 \%$ and $80 \%$ of the bottom area. The concrete tanks were equipped with a flow-through water circulation system. The business feasibility of the culture system was calculated using the revenue cost ratio $(R / C)$ formula. The results showed that the growth in length, shell width and weight at a density of $70 \%$ was better than that of the density of $80 \%$ The density of $70 \%$ resulted in an $8.98 \%$ increase in biomass yield and a $6.51 \%$ mortality higher than a density of $80 \%$ Based on the economic analysis, this nursery system is economically feasible where the stocking density of $70 \%$ of the total bottom area has the best financial return.

\section{KEYWORDS: abalone; stocking density; flowing tank; growth}

\section{PENDAHULUAN}

Abalon dikenal sebagai hewan yang tumbuh sangat lambat, berbeda dengan jenis hewan laut lainnya

\footnotetext{
\# Korespondensi: Balai Besar Riset Perikanan Budidaya Laut dan Penyuluhan Perikanan. Jl. Br. Gondol, Kecamatan Gerokgak Kabupaten Buleleng, Kotak Pos 140, Singaraja, Bali 811016, Indonesia

E-mail: rimgdl@ indosat.net.id
}

seperti ikan atau udang. Viana (2002) melaporkan bahwa untuk mencapai ukuran pasar, budidaya abalon memerlukan waktu pemeliharaan sekitar 2-3 tahun. Sementara itu, pemeliharaan abalon Haliotis discus di Jepang, dari telur sampai dewasa biasanya memerlukan waktu pemeliharaan sekitar 4-5 tahun sampai mencapai ukuran pasar (Takashi, 1980; Ikenoue \& Kafuku, 1992). Sintasan benih abalon (H. asinina) dilaporkan masih sangat rendah sekitar $0,6 \% 1,0 \%$ 
(Priyambodo et al., 2005); sementara itu, sintasan benih abalon $H$. squamata dapat mencapai sekitar $18,0 \%$ (Rusdi et al., 2009). Balai Besar Riset Perikanan Budidaya Laut, Gondol telah mulai penelitian tentang perbenihan abalon dan produksi benih skala massal di hatchery (Susanto et al., 2007; Rusdi et al., 2009) dan pembesaran abalon, Haliotis squamata dalam keramba apung (Susanto et al., 2012).

Rintisan ke arah komersialisasi telah dilakukan untuk pembesaran juvenil hingga ukuran tertentu. Upaya tersebut berpeluang memenuhi kebutuhan pasar domestik maupun ekspor dengan segmentasi kegiatan pendederan dari juvenil ukuran $<1 \mathrm{~cm}$ hingga $2 \mathrm{~cm}$ dengan lama pemeliharaan sekitar 2-3 bulan. Teknologi perbenihannya cukup sederhana dan mudah diadopsi oleh masyarakat.

Upaya yang perlu dilakukan pada budidaya abalon adalah peningkatan kualitas dan kuantitas benih secara berkesinambungan. Budidaya abalon yang padat modal menuntut agar sarana dan prasarana untuk budidaya dibuat lebih efisien dan murah. Hal ini dapat dilakukan dengan meningkatkan padat penebaran dan tetap mempertahankan kualitas air, serta pemberian pakan yang optimal. Penelitian ini bertujuan untuk membandingkan pertumbuhan dan produksi abalon yang dipelihara dengan padat tebar berbeda pada pendederan abalon yang dipelihara di tangki dengan sistem air mengalir.

\section{BAHAN DAN METODE}

\section{Wadah Penelitian}

Desain tangki air mengalir menggunakan bak polikarbonat berbentuk trapesium sebanyak dua buah dengan luas $2.376 \mathrm{~cm}^{2}$; debit air 49,8 L/menit dengan interval jatuhnya air ke bak pemeliharaan 3,47 menit. Air dijatuhkan dari tangki mengalir ke bak pemeliharaan (Gambar 1A). Teknik ini mengadopsi metode Vivanco-Aranda et al. (2010) tentang Recircu- lating Aquaculture System and Flow-through sistem. Pendederan abalon menggunakan dua bak beton berukuran panjang, lebar, tinggi masing-masing yaitu $12 \mathrm{~m} \times 0,8 \mathrm{~m} \times 0,8 \mathrm{~m}$ (Gambar 1B).

\section{Hewan Uji}

Benih abalon yang digunakan memiliki ukuran 4,0 $\pm 0,3 \mathrm{~cm}$. Perlakuan yang dicoba dalam penelitian ini adalah kepadatan yang berbeda, yaitu (A) 70\%dan (B) $80 \%$ dari luasan dasar bak atau setara dengan (A) 5.346 ekor/bak dan (B) 6.110 ekor/bak.

\section{Pendederan}

Sebelum ditebar, benih abalon terlebih dahulu diadaptasikan pada kondisi media pemeliharaan selama tujuh hari. Penelitian pendederan ini dilakukan selama enam bulan. Pemberian pakan Gracillaria sp. yang diperoleh dari laut atau tambak diberikan sebanyak 10\% 15\% dari biomassa setiap 2-3 hari sekali. Pembersihan dasar wadah pemeliharaan dilakukan setiap hari untuk membersihkan sisa pakan dan kotoran abalon.

\section{Parameter Uji dan Analisis Data}

Jumlah hewan uji yang digunakan sebanyak 100 ekor diambil secara acak. Peubah yang diamati meliputi pertumbuhan panjang cangkang, pertambahan bobot, persentase pertambahan bobot yang diukur setiap bulan, dan sintasan benih abalon pada akhir pemeliharaan. Pertambahan bobot $(\mathrm{g})=$ bobot akhirbobot awal. Persentase pertambahan bobot biomassa $(\%)=$ (bobot akhir biomassa-bobot awal biomassa)/ bobot awal biomassa $\times 100$. Pada akhir penelitian dilakukan analisis proksimat daging dengan metode AOAC (1985). Analisis ekonomi revenue/cost ratio dilakukan dengan membandingkan antara total penerimaan dengan total biaya (Soekartawi, 2006). Sebagai data penunjang dilakukan pengukuran kual itas air yaitu suhu, salinitas, kadar oksigen terlarut (DO), dan $\mathrm{pH}$. Data dianalisis secara deskriptif.

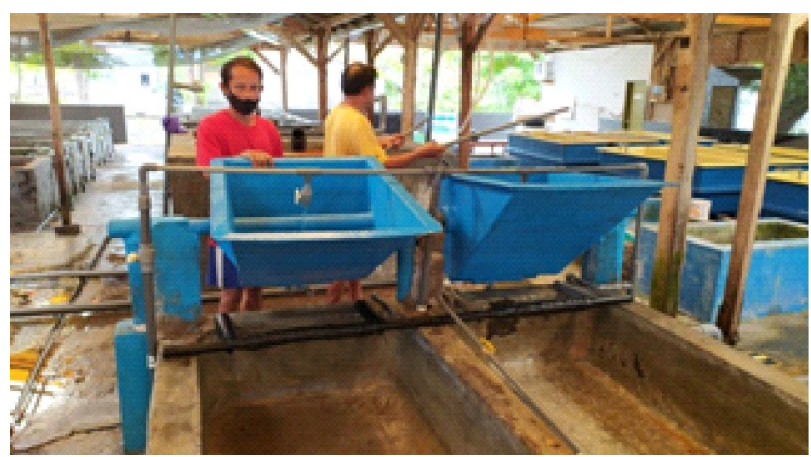

A

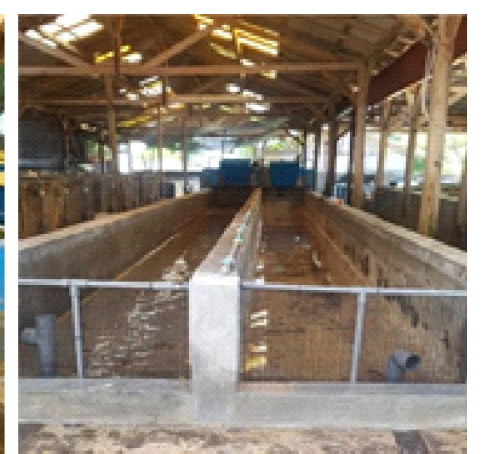

B

Gambar 1. Desain bak air mengalir dan bak pembesaran abalon.

Figure 1. Race way tank design and rearing tank of mass abalone culture. 


\section{HASIL DAN BAHASAN}

\section{Pertumbuhan}

Pertumbuhan panjang cangkang, lebar cangkang, dan pertambahan bobot abalon pada padat tebar $70 \%$ dan 80\%tersaji pada Gambar 2.

Pertumbuhan cangkang abalon yang dipelihara selama enam bulan menunjukkan hasil yang hampir sama dengan panjang $47,72 \pm 3,76 \mathrm{~mm}$ pada perlakuan A, dan perlakuan B 47,60 $\pm 3,55 \mathrm{~mm}$ (Gambar 2A). Pada Gambar 2B, terlihat bahwa pertumbuhan lebar cangkang abalon yang diamati pada akhir penelitian berturut-turut adalah A $(29,68 \pm 2,79 \mathrm{~mm})$ dan B $(29,42 \pm 2,41 \mathrm{~mm})$ (Gambar 2B). Bobot badan pada perlakuan A lebih baik dari dari perlakukan $B$, secara keseluruhan meningkat sampai akhir penelitian, yaitu $18,72 \pm 3,81 \mathrm{~g}$ dan 17,91 \pm 2,60 g (Gambar 2C). Ketika mengevaluasi kinerja pertumbuhan, dari kedua model pemeliharaan korelasi positif dan hubungan fungsional antara parameter lingkungan dan pertumbuhan (Lopez et al., 2021).

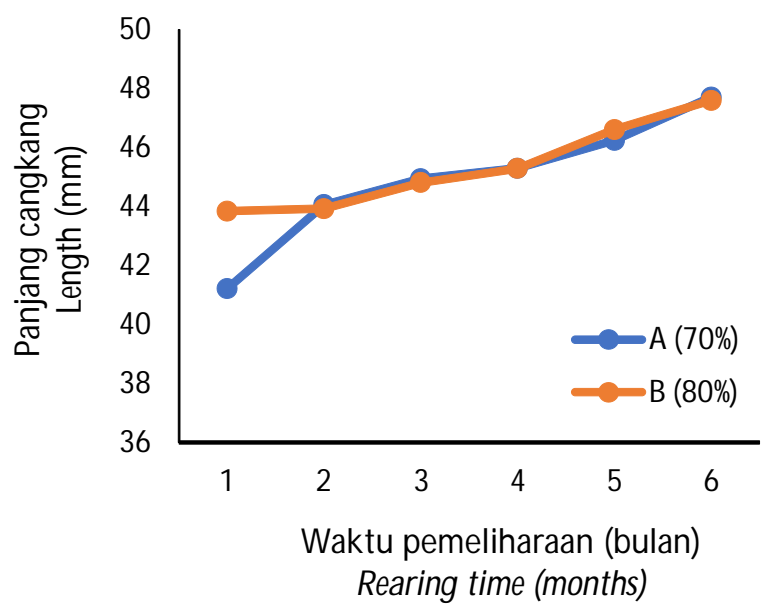

Dengan semakin tingginya padat penebaran, areal substrat yang tersedia bagi setiap individu abalon akan berkurang dan, dengan demikian, ketersediaan pakan juga akan berkurang.

Juvenil abalon yang dipeliharan dengan kepadatan tinggi dapat merespons pakan yang diberikan berupa pelet dan Gracillaria. Terlihat adanya peningkatan ukuran panjang cangkang, namun tingkat pertumbuhan bobotnya kurang optimal. Hal ini terlihat dari ruang yang padat dan arus yang timbul akibat aliran tangki air mengalir pada pemeliharaan ini berpengaruh terhadap pertumbuhannya (Gambar 3).

Pemberian pakan Gracilaria verrucosa dilakukan pada juvenil abalon umur 6-7 bulan dan menunjukkan pertumbuhan yang baik (Effendy, 2007). Menurut Schiel (2021), bahwa pakan Gracilaria verrucosa memberikan pengaruh yang terbaik terhadap pertumbuhan panjang dan bobot pada juvenil abalon. Pendapat yang sama juga dilaporkan Fermin \& Buen (2002) bahwa pakan makroalga seperti rumput laut Gracillaria sp. sangat berperan dalam pertumbuhan benih abalon. Pakan

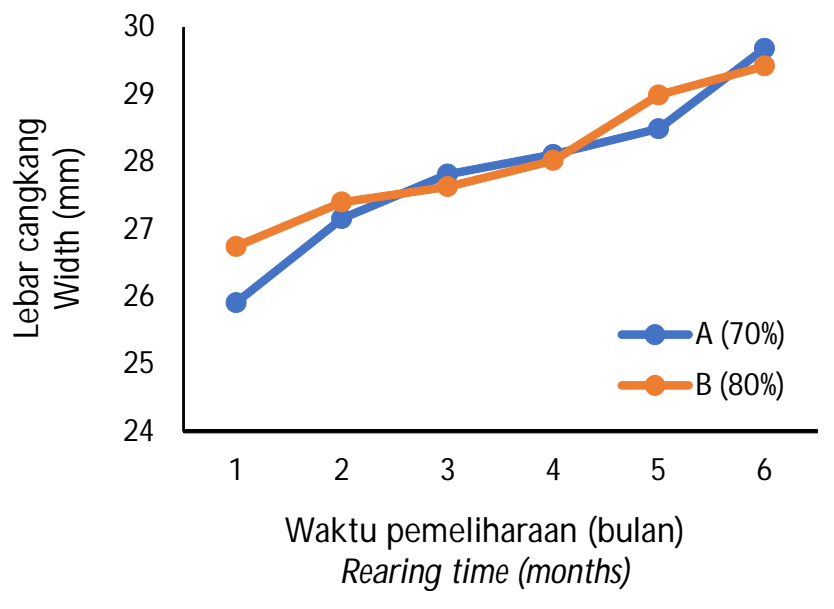

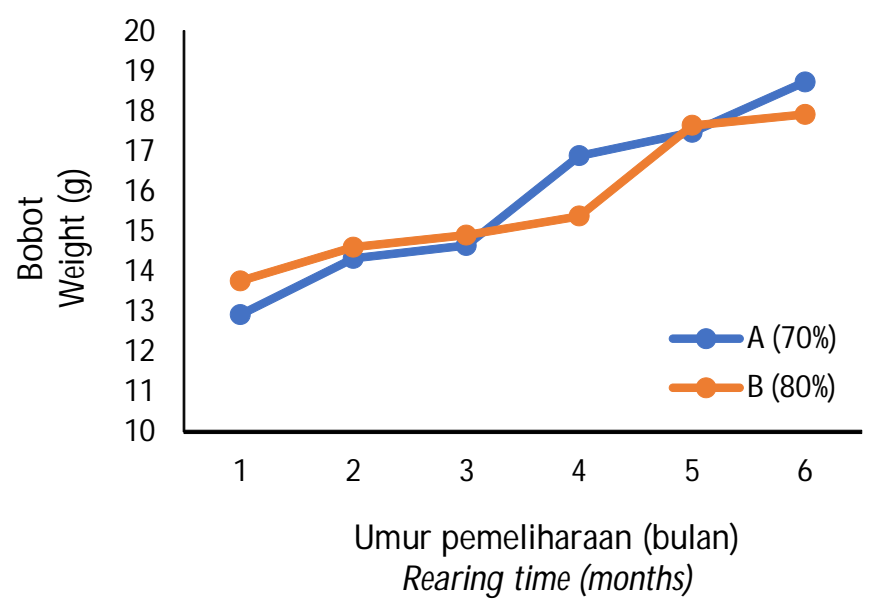

Gambar 2. Pertumbuhan panjang cangkang (A), lebar cangkang (B), dan bobot (C) dari abalon yang dipelihara dengan padat tebar berbeda selama enam bulan pad sistem air mengalir.

Figure 2. Growth of shell length (A), width (B), and total weight $(C)$ of juvenile abalone during the experiment. 

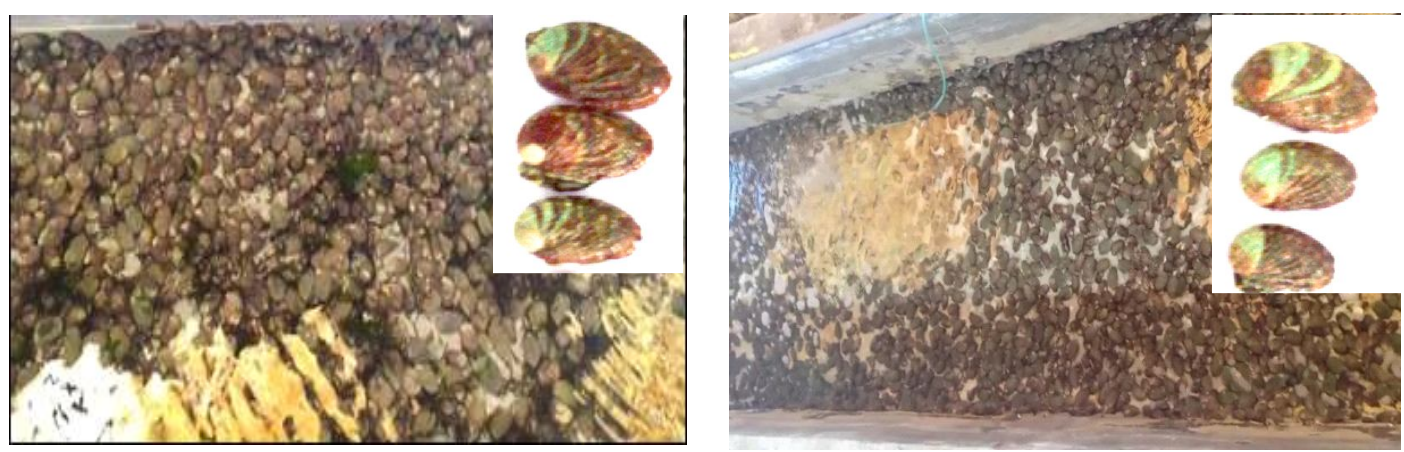

Gambar 3. Kepadatan juvenil abalon pada kepadatan 70\%(A) dan $80 \%(B)$.

Figure 3. Density of abalone juveniles at the densities of $70 \%(\mathrm{~A})$ and $80 \%(\mathrm{~B})$.

buatan dengan proporsi Ulva sp. dan Gracilaria sp. yang berbeda dalam pakan pelet dapat meningkatkan pertumbuhan dan menurunkan konversi pakan (Marzuqi et al., 2012).

\section{Sintasan}

Sampai akhir penelitian diperoleh sintasan pada perlakuan A $(78,00 \%)$ dan B $(73,20 \%)$ (Gambar 4$)$. Sintasan tertinggi dicapai pada perlakuan $A$, hal ini diduga disebabkan oleh kondisi ruang yang lebih luas dibandingkan dengan perlakuan B. Namun demikian, sintasan abalon selama pemeliharaan pada kedua perlakuan (A dan B) mempunyai nilai yang cukup tinggi. Hal ini menunjukkan bahwa secara fisiologi abalon yang dipelihara pada kepadatan tinggi dengan sistem tangki air mengalir berada pada batasan yang masih layak dalam kehidupan abalon ( $H$. squamata). Pada kepadatan tebar tinggi, abalon dibatasi dengan ruang gerak sehingga sulit dalam mencari makanan karena berhimpitan saat bergerombol. Kondisi ini dapat memengaruhi pertumbuhan dan tingkat sintasan (Huchette et al., 2003).

\section{Analisis Proksimat}

Protein memegang peranan penting dalam struktur dan fungsi tubuh terutama dalam pertumbuhan dan reproduksi. Oleh karena itu, protein merupakan bagian terbesar dari otot daging (Villanueva \& Bustamante, 2006). Kadar protein dalam tubuh merupakan senyawa yang kandungannya paling tinggi. Analisis proksimat daging abalon dalam studi ini disajikan pada Tabel 1.

Proksimat daging abalon kering terlihat adanya perbedaan pada kandungan proteinnya. Hasil ini terlihat selaras dengan Wilbur (1983) dan Tsai (2018) yang mengemukakan bahwa kandungan protein pada kebanyakan kerang disimpan di dalam gonad dan otot aduktor untuk kebutuhan gametogenesis. Sehingga diduga semakin besar ukuran cangkang dan ukuran otot aduktor kebutuhan protein juga akan bertambah.

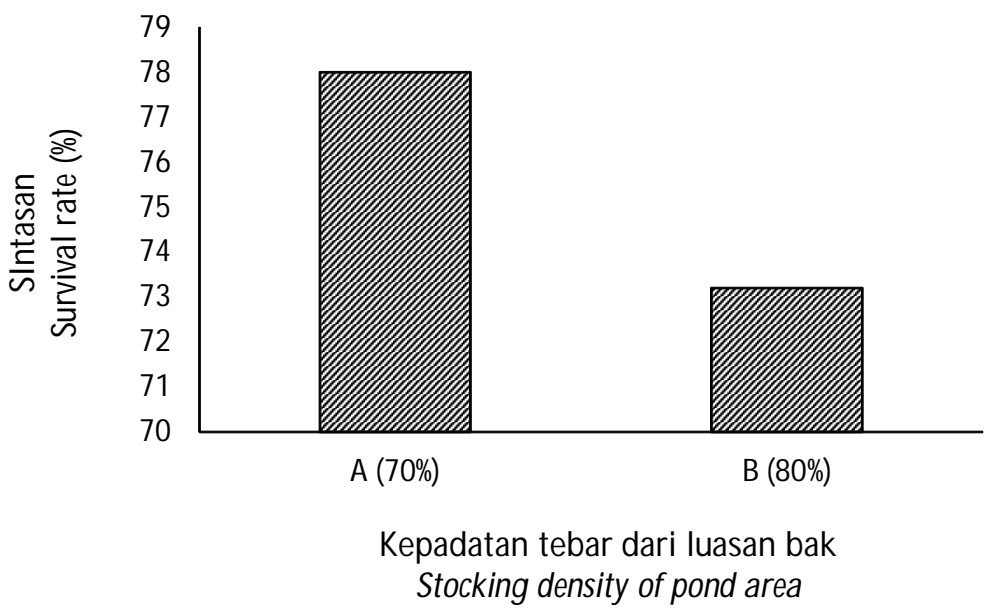

Gambar 4. Sintasan juvenile abalon dengan dengan sistem tangki air mengalir.

Figure 4. Survival rate of abalone juveniles at the densities of $70 \%$ (A) and $80 \%(B)$. 
Tabel 1. Kandungan proksimat bahan kering dari daging abalon, H. squamata yang dipelihara pada padat tebar tinggi dengan sistem air mengalir

Table 1. Proximate content of dry meat abalone, H. squamata at high stocking densities with flowing tank systems

\begin{tabular}{lcc}
\hline \multirow{1}{*}{$\begin{array}{c}\text { Parameter } \\
\text { Parameters }\end{array}$} & \multicolumn{2}{c}{$\begin{array}{c}\text { Padat tebar abalon } \\
\text { Stocking density of abalone }\end{array}$} \\
\cline { 2 - 3 } & $\mathbf{A ~ ( \mathbf { 7 0 } \%}$ & $\mathbf{B ~ ( 8 0 \% )}$ \\
\hline Kadar abu (Ash) (\%) & 7.3 & 6.79 \\
Kadar lemak (Lipid) (\%) & 6.35 & 6.46 \\
Kadar protein (Protein) (\%) & 71.21 & 68.69 \\
\hline
\end{tabular}

\section{Nilai Kualitas Air}

\section{Oksigen terlarut}

Nilai oksigen terlarut pada penelitian yang diamati per satuan waktu dan tempat (inlet, tengah, dan outlet) terlihat pada (Gambar 5). Pada pemeliharaan abalon dengan kepadatan tinggi pada sistem ini pergantian air segar harus tetap konstan dengan interval tidak melebihi 30 menit untuk menjaga konsentrasi oksigen terlarut berada pada kondisi optimal $>4 \mathrm{mg} / \mathrm{L}$ (Gambar 5).

Kelarutan oksigen media pemeliharaan dapat ditingkatkan dengan adanya jatuhnya massa air yang menimbulkan aliran arus (Rusdi et al., 2009). Hal ini disinyalir dapat meningkatkan kelarutan oksigen dan pembilasan (flushing) di bak pemeliharaan abalon dengan kepadatan tinggi. Tingginya pergantian air penting untuk menjaga kualitas air seiring dengan meningkatnya padat penebaran (Steinarsson $\&$ Albert, 2003).

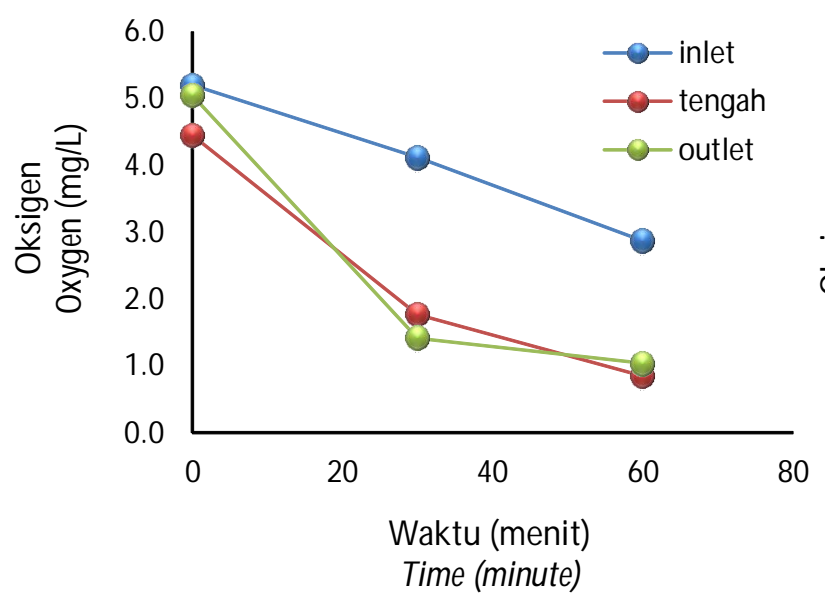

\section{Suhu}

Hasil pengukuran suhu air pada bak pemeliharaan memiliki kisaran $27,8^{\circ} \mathrm{C}-29,8^{\circ} \mathrm{C}$ (A) dan $27,8^{\circ} \mathrm{C}-29,0^{\circ} \mathrm{C}$ (A). Hal ini menunjukkan bahwa kisaran nilai yang diperoleh masih berada dalam batas yang layak untuk budidaya abalon dan selaras dengan yang disampaikan Susanto et al. (2010) bahwa suhu air ideal untuk pendederan abalon di bak berkisar $27,2^{\circ} \mathrm{C}-29,9^{\circ} \mathrm{C}$.

\section{Salinitas}

Salinitas selama penelitian berkisar antara 33-34 ppt. Menurut Setiawati et al. (1995), melaporkan bahwa abalon dapat hidup pada kisaran salinitas 35$37 \mathrm{ppt}$, namun pada salinitas di atas $35 \mathrm{ppt}$ pertumbuhan biota laut dapat terhambat (Kordi, 2008).

\section{pH}

Hasil pengukuran pH selama pemeliharaan menunjukkan bahwa kisaran nilai konstan di nilai 8,08,1 berada dalam batas yang layak bagi kehidupan abalon.

Gambar 5. Hasil pengamatan kadar oksigen abalon pada inlet, tengah, dan outlet dengan sistem tangki air mengalir.

Figure 5. Dissolve oxygen condition of inlet, center, and outlet with a flowing tank system. 


\section{Amonia}

Secara umum konsentrasi amonia dalam media pemeliharaan pada kedua perlakukan berada pada nilai normal yaitu $<0,5 \mathrm{mg} / \mathrm{L}$. Rendahnya nilai amonia pada media pemeliharan dapat disebabkan karena sistem tangki air mengalir ini secara langsung dapat mengeluarkan feces yang hanyut bersamaan dengan arus air.

\section{Analisis Ekomomi}

Hasil analisis ekonomi penerapan sistem tangki air mengalir pada pendederan abalon kepadatan tinggi, dilakukan analisis ekonominya dengan membandingkan dengan sistem pendederan di bak beton (sirkulasi) yang dilakukan di masyarakat, selengkapnya tersaji pada Tabel 2.
Nilai $\mathrm{R} / \mathrm{C}$ rasio pada pendederan dengan flowing tank per siklus $>1$ yang menunjukkan bahwa kelayakan ekonomis usaha pendederan sistem tangki air mengalir layak untuk diusahakan. Pendederan abalon dengan sistem tanki air mengalir dinyatakan layak atau masih dalam tingkat efisiensi karena nilai $\mathrm{R} / \mathrm{C}$ ratio lebih dari satu yang artinya nilai penerimaan lebih besar dari total biaya. Semakin besar nilai R/C ratio maka semakin besar pula tingkat efisiensi suatu usaha (Sososutiksno \& Gaspertz, 2017).

\section{KESIMPULAN}

Pendederan abalon secara massal dapat dilakukan dengan sistem tangki air mengalir menggunakan kepadatan $70 \%$ dari luasan bak pemeliharaan. Kepadatan $70 \%$ menghasilkan peningkatan biomassa dan sintasan paling baik. Juvenil abalon dapat tumbuh pada

Tabel 2. Analisis usaha pendederan abalon kepadatan tinggi dengan sistem tangki air mengalir dan sirkulasi.

Table 2. Business analysis of high density abalone nursery with the water flow-through system as the treatment and a circulating water systems as control)

\begin{tabular}{|c|c|c|c|c|}
\hline \multirow[b]{2}{*}{$\begin{array}{l}\text { Uraian } \\
\text { Description }\end{array}$} & \multirow[b]{2}{*}{ Volume } & \multirow[b]{2}{*}{$\begin{array}{l}\text { Satuan } \\
\text { Unit }\end{array}$} & $\mathbf{A}$ & $\mathbf{B}$ \\
\hline & & & $\begin{array}{c}\text { Bak beton } \\
\text { Flowing tank }\end{array}$ & $\begin{array}{l}\text { Bak beton sirkulasi } \\
\text { Circulation flowing tank }\end{array}$ \\
\hline \multicolumn{5}{|l|}{ Biaya tetap (Fixed cost) } \\
\hline Sewa lahan (Land lease) & 10 & Tahun (Year) & $30,000,000$ & $70,000,000$ \\
\hline Bak pemeliharaan (Rearing tank ) & 10 & Unit & $16,500,000$ & $75,000,000$ \\
\hline $\begin{array}{l}\text { Instalasi tangki air mengalir } \\
\text { Instalattion of flowing tank }\end{array}$ & 10 & Unit & $4,500,000$ & \\
\hline Pemipaan (Pipe installation) & 10 & Unit & $10,000,000$ & $20,000,000$ \\
\hline Blower (Blower) & 1 & Unit & $5,000,000$ & $5,000,000$ \\
\hline Instalasi aerasi (Aeration installation ) & 10 & Unit & 300,000 & $1,500,000$ \\
\hline Listrik (Electricity) & 1 & Unit & $1,500,000$ & $2,500,000$ \\
\hline Instalasi listrik (Electrical instalation) & 1 & Unit & $2,000,000$ & $1,000,000$ \\
\hline Pompa 2 inci (Pump 2 inchi ) & 2 & Unit & $4,000,000$ & $4,000,000$ \\
\hline Pembuatan atap hatcheri (Hatchery roofing ) & 1 & Unit & $7,000,000$ & $15,000,000$ \\
\hline Total biaya investasi & & & $80,800,000$ & $194,000,000$ \\
\hline \multicolumn{5}{|l|}{ Biaya tetap (Fixed cost) } \\
\hline a. Tenaga kerja (Labor) & 12 & Bulan (M onth) & $24,000,000$ & $24,000,000$ \\
\hline b. Biaya penyusutan (Cost of depreciation ) & 1 & Siklus (Cycle) & $6,900,000$ & $1,016,000$ \\
\hline \multicolumn{5}{|l|}{ Biaya variabel (Nariable cost) } \\
\hline a. Benih (Seed) & 50,000 & Ekor & $75,000,000$ & $75,000,000$ \\
\hline b. Pakan (Feed) [FCR 20] & 19,200 & $\mathrm{Kg}$ & $28,800,000$ & $28,800,000$ \\
\hline c. Langganan daya (Electricity subscription ) & 12 & Bulan (M onth) & $18,000,000$ & $30,000,000$ \\
\hline Total biaya (Total cost) (Rp) & & & $152,700,000$ & $158,816,000$ \\
\hline $\begin{array}{l}\text { Produksi (biomassa dalam kg) } \\
\text { Production (biomass in kg) }\end{array}$ & & & 936 & 878.4 \\
\hline Harga produksi (Production price) (Rp) & & & 200,000 & 200,000 \\
\hline Pendapatan kotor (Gross income) (Rp) & & & $187,200,000$ & $175,680,000$ \\
\hline $\begin{array}{l}\text { Pendapatan bersih (Net income) (Rp) } \\
\text { Siklus } 6 \text { bulan ( } 6 \text { month cycle) }\end{array}$ & & & $34,500,000$ & $16,864,000$ \\
\hline $\mathrm{R} / \mathrm{C}$ rasio ( $\mathrm{R} / \mathrm{C}$ ratio) & & & 1.23 & 1.11 \\
\hline
\end{tabular}


kepadatan tinggi dengan sistem tangki air mengalir. Sistem tanki air mengalir ini dinyatakan layak $\mathrm{R} / \mathrm{C}$ rasio $>1$. Adanya arus air dari tangki air mengalir memegang peran kunci pada pendederan abalon kepadatan tinggi.

\section{UCAPAN TERIMA KASIH}

Dengan telah dilaksanakan penelitian abalon ini, kami mengucapkan banyak terima kasih kepada teknisi abalon yang telah banyak membantu dalam pelaksanaan penelitian ini.

\section{DAFTAR ACUAN}

Association of Official Analytical Chemist (AOAC). (1985). Official methods of analysis. 12th Edition. Association of Official Analytical Chemist. Washington D.C., 1141 pp.

Effendy, I. J. (2007). Pengembangan teknologi pembenihan dan budidaya abalon (Haliotis asinina) di Indonesia. hIm. 1-3. Seminar Nasional Molluska. Universitas Diponegoro, Semarang.

Fermin A.C. \& Buen, S.M. (2002). Grow-out culture of tropical abalone, Haliotis asinina (Linnaeus), in suspended mesh cages with different shelter surface area. Aqua. Int., 9, 499-508.

Huchette, S.M.H., Koh, C.S., \& Rob, W.D. (2003). Growth of juvenile blacklip abalone (Haliotis rubra) in aquaculture tanks: Effects of density and ammonia. Aquaculture, 219, 457-470.

Ikenoue H. \& Kafuku, T. (1992). Modern methods of aquaculture in Japan. Tokyo: Elsevier, Kadansha Ltd., p. 206-216.

Kordi, G. (2008) Budidaya perairan. Jilid 1. Bandung: PT Citra Aditya Bakti.

Lopez, V.G.V., Solana, F.V., \& Sanches, F.A. (2021). Effect of environmental variability on the individual growth of yellow abalone (Haliotis corrugata) and blue abalone (Haliotis fulgens) in the Mexican Pacific. Regional Studies in Marine Science, 46(2), 101877.

Marzuqi, M., Rusdi, I., \& Susanto, B. (2012). Aplikasi pakan buatan pada pemeliharaan benih abalon (Haliotis squamata). J. Ris. Akuakultur, 7(2), 237-245.

Priyambodo, B., Sofyan, Y., \& Suastika, I.B.M. (2005). Produksi benih tiram abalon (Haliotis asinine) di Loka Budidaya Laut Lombok. Yogyakarta, hlm. 144148.

Rusdi, I., Susanto, B., \& Rahmawati, R. (2009). Pemeliharaan abalon Haliotis squamata dengan sistem pergantian air yang berbeda. Prosiding Semi- nar Nasional Moluska 2, "M oluska Peluang Bisnis dan Konservasi". Bogor: FPIK-IPB, V, 72-81.

Salim, N.M., Susilastuti, D., \& Setyowati, R. (2017). Pengaruh faktor produksi terhadap pendapatan dan implikasinya terhadap nilai tukar petani kentang. Studi kasus petani kentang di Kecamatan Kejajar, Wonosobo; Kecamatan Cikajang, Garut; dan Kecamatan Pangalengan, Bandung Barat. Agrisia, 9(2), 45-63.

Schiel, D.R. (2021). Review of abalone culture and research in New Zealand. June 2013. Molluscan Research, 18(2), 289-298.

Setiawati, K.M., Yunus, Setyadi, I., \& Arfah, R. (1995). Pendugaan musim pemijahan abalon di Pantai Kuta Lombok Tengah. J. Pen. Perik. Indonesia, 3, 124129.

Soekartawi. (2006). Analisis Usaha Tani. Jakarta: UI Press.

Sososutiksno, C. \& Gaspertz, J. (2017). Economic and financial feasibility of abalone culture development in Hulaliu village, District of Maluku Tengah, Maluku Province. AACL Bioflux, 10(6), 1492-1498.

Steinarsson, A. \& Albert, K.I. (2003). Size dependent variation in optimum growth temperature of red abalone (Haliotis rufescens). Aquaculture, 224, 353362.

Susanto, B., Hanafi, H., Zafran, \& Ismi, S. (2007). Pematangan gonad induk dan perbaikan kualitas benih abalon (Haliotis squamata). Laporan Teknis BBRPBL- Gondol Bali, $17 \mathrm{hlm}$.

Susanto, B., Rusdi, I., Ismi, S., \& Rahmawati, R. (2010). Pemeliharaan yuwana abalon (Haliotis squamata) turunan $\mathrm{F}-1$ secara terkontrol dengan jenis pakan berbeda. J. Ris. Akuakultur, 5(2), 199-209.

Susanto, B., Rusdi, I., \& Khotimah, E.K. (2012). Aplikasi teknik pembasaran abalon (Haliotis squamata) dalam keramba apung untuk mendukung pengembangan budidaya. Prosiding FITA-Indoaqua. Jakarta: Puslitbang Perikanan Budidaya, hlm. 169177.

Takashi. (1980). Abalone and their industry in Japan. Tokyo: Ministry of Agriculture, Forestry and Fisheries, p. 165-177.

Tsai C.L., Shiau C.Y., Hsiao, H.I., \& Sung, W.C. (2018). Proximate composition and free nitrogen-containing compounds in raw hybrid abalone (haliotis discus hannai h. Diversicolor diversicolor), commercial processed abalone and abalone ana- 
logue products. Journal of Marine Science and Technology ÿ 26wS1g, p. 137 -143.

Viana, T.M. (2002). Abalon aquaculture an overview in manual of fish culture. World Aquaculture, 33(1), 34-39.

Villanueva, R. \& Bustamante, P. (2006). Composition in essential and non-essential elements of early stages of chepalopods and dietary effects on the elemental profiles of octopus Vulgaris paralarvae. Aquaculture, 261, 225-240.
Vivanco-Aranda, M., Gallardo-Escarate, C.J., \& del RioPortilla, M.A. (2010). Low-density culture of red abalone juveniles, Haliotis rufescens Swainson 1822, Recirculating Aquaculture System and Flowthrough System. Aquaculture, Research, p. 1-8.

Wilbur, K.M. (1983). The mollusca: Environmental biochemstry and physiology. Volume II. Edited by: Peter .W. Hochachka). New York: Academic Press Inc., $362 \mathrm{pp}$. 